\title{
Analisis Respon dan Ketertarikan Peserta Didik Terhadap Pelaksanaan Pembelajaran Fisika Berbasis Environmental Learning di SMA
}

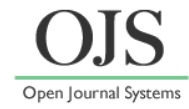

\author{
Putih Sari"' Dwikoranto dan Nurita Apridiana Lestari \\ Jurusan Fisika, Fakultas Matematika dan Ilmu Pengetahuan Alam, Universitas Negeri Surabaya \\ *Email: putih.17030184044@mhs.unesa.ac.id
}

DOI: https://doi.org/10.33369/pendipa.5.3.337-344

\begin{abstract}
Environmental Learning is an environment-based learning process that is developed so that students can gain learning experiences that are related to the surrounding environment. This study aims to analyze the responses of students to the implementation of environment-based physics learning in high schools involving 100 students in 6 schools in Gresik Regency using quantitative methods to analyze a questionnaire containing student's response. Student responses are categorized into 3 aspects, namely student's responses to physics learning, the methods used by the teacher in delivering material, and environmental learning-based physics learning is interested or not was carried out. The results of the questionnaire stated that as many as 54\% of students said physics lessons were difficult to learn because students needed more varied physics learning methods. This proves that the method used by the teacher has not had an influence on the ability of students so that $95 \%$ of students say that they are interested if physics learning is carried out based on environmental learning with the aim that students can more easily understand physics by utilizing it in everyday life and increasing development the ability of students to reason and analyze a problem.
\end{abstract}

Keywords: Environmental Learning, Response Analysis, Interest.

\begin{abstract}
ABSTRAK
Environmental Learning merupakan proses pembelajaran berbasis lingkungan yang dikembangkan agar peserta didik dapat memperoleh pengalaman belajar yang memiliki kaitan dengan lingkungan sekitar. Penelitian ini bertujuan untuk menganalisis respon peserta didik terhadap dilaksanakannya pembelajaran fisika yang berbasis lingkungan di SMA yang melibatkan 100 peserta didik di 6 sekolah di Kabupaten Gresik. Penelitian ini menggunakan metode kuantitatif untuk menganalisis angket yang berisi respon peserta didik. Respon peserta didik dikategorikan menjadi 3 aspek yakni respon peserta didik terhadap pembelajaran fisika, metode yang digunakan guru dalam menyampaikan materi, dan tertarik atau tidaknya dilakukan pembelajran fisika berbasis environmental learning. Hasil dari angket tersebut menyatakan bahwa sebanyak $54 \%$ peserta didik mengatakan pelajaran fisika sulit untuk dipelajari karena peserta didik memerlukan metode pembelajaran fisika yang lebih variatif. Hal tersebut membuktikan bahwa metode yang digunakan guru belum memiliki pengaruh pada kemampuan peserta didik sehingga $95 \%$ peserta didik mengatakan tertarik apabila dilaksanakan pembelajaran fisika yang berbasis environmental learning dengan tujuan agar peserta didik dapat lebih mudah memahami ilmu fisika dengan memanfaatkannya dalam kehidupan sehari-hari serta menumbuhkembangkan kemampuan peserta didik dalam menalar dan menganalisis suatu permasalahan.
\end{abstract}

Kata kunci: Environmental Learning, Analisis Respon, Ketertarikan.

\section{PENDAHULUAN}

Pembelajaran dapat dikatakan sebagai suatu proses untuk mencapai tujuan tertentu dalam kegiatan belajar mengajar yang merupakan terjadinya interaksi antara peserta didik dan guru (Sudjana, 2010). Pendidikan merupakan suatu usaha yang dilakukan secara sadar untuk dapat menumbuhkan kemampuan yang dimiliki oleh setiap manusia melalui proses pembelajaran (Rohani, 2018). Pada pelaksanaan proses pembelajaran terdapat kompetensi dasar yang dapat disebut sebagai 
serangkaian kemampuan yang terdiri atas kemampuan kognitif, afektif, dan psikomotor yang dapat tercermin dalam sikap peserta didik melalui proses. Tujuan utama dalam pelaksanaan suatu pembelajaran di sekolah yakni dapat menjadi salah satu acuan pendidikan agar peserta didik dapat mencapai kompetensi dasar sesuai dengan rencana yang sudah dibuat sebelumnya. Pencapaian tujuan pembelajaran dapat dilakukan melalui metodemetode yang diberikan oleh guru agar materi dapat diterima dengan baik oleh peserta didik yang salah satunya adalah dengan mengkaitkan konsep-konsep pembelajaran kedalam kehidupan sehari-hari.

Konsep-konsep pembelajaran yang dapat dikaitkan kedalam kehidupan sehari-hari adalah melalui ilmu-ilmu fisika. Ilmu-ilmu fisika dapat disampaikan kepada peserta didik melalui berbagai macam proses pembelajaran, salah satunya ialah pembelajaran fisika itu sendiri. Pembelajaran fisika merupakan salah satu proses ilmiah yang terdiri dari tiga komponen penting yakni konsep, prinsip, dan teori melalui serangkaian proses ilmiah (Trianto, 2010). Pembelajaran fisika memiliki peran penting dalam proses pendidikan dan perkembangan teknologi dunia. Tujuan pembelajaran fisika sendiri adalah supaya peserta didik dapat menerapkan pengetahuan yang dimiliki dan dikuasai untuk memecahkan masalah yang ada pada kehidupan sehari-hari (Hedge \& Meera, 2012).

Peserta didik mengalami berbagai macam kesulitan dalam memahami suatu pengetahuan, salah satu penyebab kesulitan tersebut terjadi karena adanya pengetahuan baru yang tidak dapat diterima peserta didik karena tidak memiliki hubungan dengan pengetahuan yang mereka peroleh sebelumnya. Kesulitan peserta didik dalam proses pembelajaran fisika meliputi materi yang tergolong sulit untuk difahami, metode pembelajaran yang dilakukan tergolong membosankan, dan kemampuan peserta didik dalam menyelesaikan suatu permasalahan (Maman, 2016). Kegiatan proses pembelajaran di sekolah merupakan suatu interaksi antara guru dengan peserta didik (Imelda \& Dewi, 2019). Proses pembelajaran fisika ini nantinya diharapkan tidak hanya berisi serangkaian kumpulan konsep, materi dan rumus-rumus saja melainkan terdapat beberapa proses pemahaman-pemahaman yang memiliki kaitan dalam kehidupan sehari-hari sehingga dapat menganalisis secara ilmiah.
Berlangsungnya proses pembelajaran fisika, peserta didik diharapkan dapat memahami dan mengaplikasikan ilmu-ilmu fisika kedalam kehidupan sehari-hari sehingga fisika tidak hanya sebagai ilmu matematis saja namun juga sebagai ilmu yang memiliki keterkaitan ilmiah dengan lingkungan yang mudah dan asik untuk dipelajari. Pada proses pembelajaran diperlukan adanya interaksi yang berupa tanggapan atau respon, baik peserta didik terhadap guru maupun sebaliknya (Simanjuntak \& Imelda, 2015). Respon peserta didik juga sangat diperlukan dalam proses pelaksanaan pembelajaran fisika yang dapat digunakan sebagai acuan dalam pelaksanaan perubahan-perubahan metode pembelajaran agar memiliki inovasi baru. Proses pembelajaran yang bersifat membosankan menurut peserta didik memiliki ciri yaitu adanya dominasi ceramah dan fokus pembelajaran yang lebih menekankan pada penyelesaian materi pelajaran serta menghafalkan materi pelajaran (Rahayu, 2012). Proses pembelajaran yang terkesan bersifat membosankan ini harus mendapatkan perhatian lebih agar dapat menumbuhkembangkan ideide kreatif serta inovatif peserta didik.

Pemanasan global saat ini merupakan topik yang masih dibacarakan oleh semua masyarakat dalam hal dampak serta cara mencegahnya. Kenaikan suhu yang ada di bumi merupakan salah satu penyebab terjadinya pemanasan global yang mengganggu keseimbangan antara komponen biotik dan abiotik di bumi (Venkataramanan \& Smitha, 2011). Permasalahan lingkungan ini dapat dicegah dengan adanya pembelajaran yang berbasis lingkungan atau yang disebut dengan environmental learning. Environmental learning sendiri merupakan suatu proses pembelajaran yang berbasis lingkungan dan dikembangkan agar peserta didik dapat memperoleh pengalaman belajar yang memiliki kaitan dengan lingkungan sekitar. Environmental learning menurut (Rickinson, 2009) disorot dalam dua cara. Pertama, environmental learning ini memiliki fokus pada alam, konservasi, dan perubahan sosial. Berdasarkan hal ini, permasalahan lingkungan merupakan permasalahan yang dipandang sebagai konteks kecil yaitu sifat yang dapat diamati oleh peserta didik pada lingkungan di sekitarnya seperti sungai, hutan, gunung, laut, dan yang lain sebagainya. Menghasilkan pemahaman baru tentang alam, pemahaman 
dan perilaku konservasi alam, dan perubahan sikap tentang alam. Kedua, environmental learning yang memiliki kaitan dengan proses dan konteks yang luas dan perlu dibedakan dalam berbagai macam sumber informasi seperti sistem pendidikan formal, buku, percakapan, dan museum (Periera, 2017). Menurut (Rickinson, 2009) hasil yang diharapkan melalui pelaksanaan pembelajaran ini yaitu nilai dan perasaan, pemahaman, perilaku, keadilan sosial, dan keterampilan yang demokratis. Hasil dari pelaksanaan pembelajaran berbasis environmental learning ini berasal dari masukan serta saran-saran yang diterima oleh para peserta didik hingga membentuk suatu pemikiran yang perspektif tentang segala sesuatu yang berada di sekitar mereka.

\section{METODE PENELITIAN}

Penelitian ini dilakukan pada bulan Desember 2020 pada 100 responden. Data yang diperoleh dalam penelitian ini merupakan data yang berasal dari angket yang telah disebarkan di beberapa SMA di Kabupaten Gresik melalui google form dan diisi oleh peserta didik sesuai dengan kondisi yang sebenarnya.

Tabel 1. Sebaran Populasi Responden Berdasarkan Asal Sekolah

\begin{tabular}{|c|l|c|}
\hline No & \multicolumn{1}{|c|}{ Asal Sekolah } & $\begin{array}{c}\text { Jumlah } \\
\text { Responden }\end{array}$ \\
\hline 1 & SMA Negeri 1 Kebomas & 42 \\
\hline 2 & SMA Negeri 1 Gresik & 38 \\
\hline 3 & SMA Negeri 1 Sidayu & 17 \\
\hline 4 & SMA Negeri 1 Manyar & 1 \\
\hline 5 & MAN 1 Gresik & 1 \\
\hline 6 & SMA Assa'adah & 1 \\
\hline \multicolumn{2}{r}{ Total } & 100 \\
\hline
\end{tabular}

Penelitian ini menggunakan metode kuantitatif yang pelaksanaan penelitiannya menggunakan lembar instrumen dalam pengambilan data untuk meneliti populasi atau sampelnya (Mulyadi, 2011). Intrumen yang digunakan dalam penelitian ini berupa angket (respon) untuk para responden dan data hasil penelitian berdasarkan angket ini disajikan dalam bentuk tabel, grafik, atau diagram yang dapat dilakukan analisis secara deskriptif (Mastuti, 2016).
Sampel pada penelitian ini terdiri atas 100 responden peserta didik dari 6 sekolah yang dipilih secara cluster random sampling di kabupaten Gresik. Cluster random sampling adalah teknik dalam pengambilan sampel data apabila sampelnya tersedia dalam beberapa rumpun dalam populasi (Setyosari, 2012). Populasi yang digunakan dalam penelitian ini yakni peserta didik pada tingkat SMA yang memilih jurusan MIPA.

\section{HASIL DAN PEMBAHASAN}

Angket respon peserta didik yang digunakan dalam penelitian ini memiliki tiga aspek yakni respon terhadap mata pelajaran fisika, metode yang biasa dilakukan oleh guru dalam menyampaikan materi, dan tertarik/tidaknya dilaksanakan pembelajaran berbasis enviromental learning. Sehingga didapatkan data penelitian berdasarkan tiga aspek tersebut adalah sebagai berikut :

Respon Peserta Didik Terhadap Mata Pelajaran Fisika

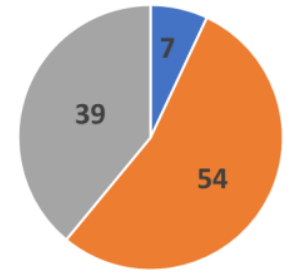

Gambar 1. Diagram Respon Peserta Didik Terhadap Mata Pelajaran Fisika

Berdasarkan diagram diatas, dapat dikatakan bahwa terdapat 7 orang peserta didik mengatakan mata pelajaran fisika itu mudah dengan alasan karena peserta didik melakukan pemahaman terhadap materi fisika melalui cara mereka sendiri, diantaranya adalah dengan mempelajari materi berulang kali, membuat catatan/rangkuman, dan merasa mudah memahami penjelasan guru karena materi disampaikan dengan jelas. Peserta didik yang mengatakan bahwa mata pelajaran fisika dianggap sulit sebanyak 54 karena anggapan dari mereka sendiri diantaranya adalah banyaknya rumus yang harus dihafalkan, merupakan pelajaran yang berisi rumus saja, dan sulit untuk difahami karena kurangnya penjelasan materi dari guru. Peserta didik yang memilih lain-lain dengan kategori 7 peserta didik mengatakan lumayan sulit, 32 peserta didik mengatakan sedang. Masing-masing 
kategori memiliki alasan diantaranya karena fisika memiliki banyak beberapa materi yang mudah difahami namun dalam penyelesaian soal sulit untuk dikerjakan, memiliki banyak rumus yang harus dihafalkan dan apabila mengalami kekeliruan dalam pengerjaan soal maka harus mengulanginya dari awal.

Aspek kedua yakni metode yang paling sering digunakan oleh guru sebagai sarana dalam penyampaian materi adalah sebagai berikut :

Metode yang Digunakan oleh Guru dalam Penyampaian Materi

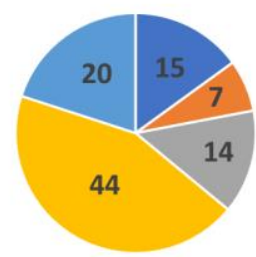

Gambar 2. Diagram Metode yang Digunakan oleh Guru Sebagai Sarana dalam Penyampaian Materi

Berdasarkan pertanyaan pada angket yang telah dibagikan, terdapat empat metode pilihan dan satu lain-lain diantaranya yakni :

\section{a. Metode Ceramah}

Berdasarkan data yang telah diperoleh dari jawaban peserta didik, metode ceramah merupakan metode yang masih menjadi metode paling sering digunakan oleh para guru dalam menyampaikan materi fisika. Jawaban angket dapat diketahui pada tabel 2 berikut :

Tabel 2. Respon Peserta Didik Tentang Pelaksanaan Pembelajaran dengan Metode Ceramah

\begin{tabular}{clc}
\hline Responden & \multicolumn{2}{c}{ Jawaban } \\
\hline $\mathbf{1}$ & $\begin{array}{l}\text { Merasa nyaman karena guru } \\
\text { menjelaskan materi dengan } \\
\text { sangat baik dan mudah } \\
\text { difahami }\end{array}$ \\
\hline $\mathbf{2}$ & $\begin{array}{l}\text { Merasa tidak nyaman karena } \\
\text { terkesan membosankan }\end{array}$ \\
\hline $\mathbf{3}$ & $\begin{array}{l}\text { Merasa kurang nyaman karena } \\
\text { penjelasannya kurang jelas dan } \\
\text { sulit untuk difahami }\end{array}$ \\
\hline $\mathbf{4}$ & $\begin{array}{l}\text { Merasa lumayan nyaman } \\
\text { bergantung dengan materi } \\
\text { yang sedang diajarkan }\end{array}$ \\
\hline
\end{tabular}

Peserta didik yang mengatakan kurang bahkan tidak nyaman sebanyak 17 orang adalah ketika guru menggunakan metode tersebut dengan penyampaian yang sulit difahami dan terkesan membosankan sehingga peserta didik tidak dapat fokus dalam melaksanakan pembelajaran.

Penggunaan metode yang kurang tepat, kurang bervariasi, dan bersifat teacher centered dalam pelaksanaan pembelajaran fisika dapat menyebabkan peserta didik berkembang menjadi pelajar yang tidak dapat megembangkan kemampuan diri secara maksimal (Nobita, 2015). Banyak peserta didik yang mengalami kesulitan memahami fisika ketika guru menyampaikan materi dengan metode ceramah.

b. Metode Pratikum

Metode pratikum merupakan metode yang cukup sering digunakan oleh guru, pada penelitian ini respon peserta didik adalah sebagai berikut : (1) Merasa nyaman karena merasa lebih mudah memahami materi dan melakukan praktik secara langsung, (2) Merasa lumayan nyaman karena guru tidak menjelaskan materi dahulu namun praktik yang dilakukan membuat peserta didik tidak merasa bosan, (3) Merasa kurang nyaman karena guru tidak menjelaskan materi yang akan dilakukan pratikum sehingga dalam proses mengerjakannya menjadi kebingungan.

Berdasarkan jawaban tersebut dapat dikatakan bahwa peserta didik memiliki minat yang cukup tinggi dalam belajar ketika guru menyampaikan materi fisika dengan menggunakan metode pratikum, peserta didik tidak hanya menerima materi saja namun melakukan praktik nyata. Ilmu fisika merupakan ilmu yang dipelajari melalui proses ilmiah, dan sikap ilmiah sehingga melalui pendekatan ilmiah ilmu fisika dapat mencapai tujuannya yang dapat digunakan oleh siapapun (Subagia, 2013). Pendekatan ilmiah yang dimaksudkan merupakan pemberian pemahaman untuk mengenal dan memahami materi fisika yang tidak bergantung kepada guru salah satunya adalah dengan penggunaan metode pratikum (Hosnan, 2014). Menggunakan metode pratikum ini diharapkan dapat menjadi salah satu metode yang dapat mengembangkan kemampuan peserta didik dalam menganalisis suatu permasalahan dengan pendekatan ilmiah. 


\section{c. Metode Diskusi}

Data pada gambar 2 yakni metode yang digunakan oleh guru, menunjukkan bahwa metode diskusi merupakan metode yang paling jarang digunakan oleh guru dalam menyampaikan materi. Penggunaan metode diskusi ini harus dilakukan dengan menganalisis kemampuan peserta didik agar diskusi dapat berjalan dengan benar. Lebih dari $80 \%$ peserta didik yang memilih metode diskusi ini mengatakan nyaman melakukan metode tersebut dengan alasan materi lebih mudah difahami karena dituntut untuk mencari tahu sendiri pemecahan masalahnya sehingga peserta didik dilatih untuk dapat mengembangkan kemampuan dalam berfikir dan dapat bertanya apabila materi belum dapat difahami.

Suatu proses belajar mengajar memiliki nilai edukatif yang terjadi karena adanya interaksi antara guru dan peserta didik dan akan menemukan berbagai macam permasalahan (Affandy, 2019). Metode diskusi ini diharapkan dapat menjadi salah satu alternatif agar tujuan dalam proses belajar mengajar dapat terpenuhi dalam segi nilai edukatifnya.

d. Metode Tanya Jawab

Berdasarkan data pada angket, mengatakan bahwa guru menyampaikan materi dengan metode tanya jawab yang diantaranya 6 peserta didik mengatakan nyaman karena guru menyampaikan materi dengan singkat dan jelas serta mudah difahami oleh peserta didik, dan 8 peserta didik lainnya merasa tidak nyaman karena guru hanya bertanya kepada siswa tanpa menjelaskan secara jelas dan terkesan menyamaratakan kemampuan peserta didik sehingga merasa kesulitan ketika menjawab pertanyaan.

Setiap guru perlu memiliki rancangan sebelum melakukan suatu proses belajar mengajar yang dapat mendorong peserta didik untuk mengembangkan kemampuan berfikirnya dengan memberikan sedikit petunjuk (Nobita, 2015). Metode tanya jawab memiliki peranan penting dalam mengembangkan kemampuan berfikir peserta didik, namun harus dilakukan dengan menganalisis kemampuan peserta didik agar pemberian pertanyaan dapat sesuai dengan tingkat kemampuan peserta didik dalam menalar suatu permasalahan.

\section{e. Lain-lain}

Berdasarkan 4 pilihan tersebut terdapat satu pilihan jawaban yakni lain-lain. 20 peserta didik mengatakan bahwa guru menyampaikan materi dengan metode pemberian tugas dan materi tanpa dijelaskan, pratikum beserta presentasi, pemberian latihan soal, ceramah dan latihan soal, serta semua metode digunakan. Peserta didik merasa tidak nyaman ketika guru hanya memberikan latihan soal tanpa dijelaskan sehingga mengalami kesulitan dalam pengerjaan latihan soal tersebut. Peserta didik merasa nyaman ketika guru menyampaikan materi dengan semua metode yang menjadi pilihan dalam angket sehingga peserta didik tidak merasa bosan ketika melakukan proses pembelajaran dan materi dapat tersampaikan dengan baik sesuai dengan kebutuhan materi tersebut.

Tingginya tuntutan kurikulum, materi yang cukup padat, dan dominasi penguasaan fisika dengan menghitung membuat guru memberikan metode yang beragam dalam menyampaikan materi (Samudra, 2014). Beragamnya metode yang digunakan membuat peserta didik tidak dapat sepenuhnya memahami materi yang disampaikan oleh guru. Proses pemahaman materi yang diberikan tidak dilakukan dengan pengaplikasian konsep fisika, sehingga terkesan membingungkan dan sulit untuk difahami oleh peserta didik.

Aspek ketiga dari angket yang dibagikan adalah tertarik/tidak apabila dilaksanakan pembelajaran yang berbasis environmental learning. Diagram pada Gambar 3 dibawah menyatakan respon peserta didik tentang dilaksanakannya pembelajaran fisika yang berbasis environmental learning. Angket yang dibagikan kepada peserta didik merupakan pertanyaan tentang tertarik/tidak apabila dilaksanakan pembelajaran fisika berbasis environmental learning. Berdasarkan hasil angket tersebut maka diperoleh respon peserta didik sebagai berikut:

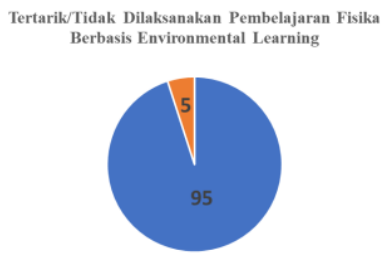

Gambar 3. Tertarik/Tidak pada pembelajaran Fisika berbasis Environmental Learning 
Dari 100 responden yang mengisi angket, terdapat 95 peserta didik mengatakan bahwa mereka tertarik apabila dilaksanakan pembelajaran fisika yang berbasis environmental learning dengan berbagai macam alasan diantaranya yakni agar peserta didik dapat memahami kaitan antara fisika dengan lingkungannya, menumbuhkan rasa keingintahuan peserta didik, menambah wawasan dalam ilmu fisika, menghilangkan rasa bosan, dan menciptakan suasana baru dalam belajar. 5 peserta didik yang mengatakan belum tertarik melakukan memiliki alasan karena belum yakin akan berjalan lebih baik dan memilih untuk menghafal rumus saja sedangkan 3 diantaranya tidak disertai alasan.

Data diatas merupakan respon peserta didik yang diisi sesuai dengan kondisi yang sebenarnya. Berdasarkan hasil angket tersebut maka dapat diketahui yakni lebih dari 50\% peserta didik mengatakan bahwa mata pelajaran fisika merupakan pelajaran yang sulit untuk dipelajari dikarenakan isi materinya memiliki banyak rumus dengan cara mengajar guru yang hanya dijelaskan singkat dan tidak dijelaskan secara runtut dari asal muasal rumus tersebut digunakan sehingga membuat peserta didik mengalami kebingungan dalam mempelajarinya. Metode yang masih sering digunakan oleh para guru untuk menyampaikan materi dalam pembelajaran fisika adalah dengan metode ceramah. Hal ini dapat menjadi bukti bahwa teknologi yang ada belum sepenuhnya dapat digunakan dan dimanfaatkan dalam dunia pendidikan (Vaselinovska, 2011). Proses pembelajaran masih didominasi dengan metode ceramah yang menyebabkan peserta didik mengalami rasa bosan dan dapat menyebabkan motivasi belajar peserta didik menjadi rendah dalam mempelajari ilmu fisika (Suparni, 2015).

Berdasarkan hasil angket, peserta didik memberikan respon yang positif yakni sebanyak $95 \%$ peserta didik dari keseluruhan responden yang mengisi angket tersebut mengatakan bahwa mereka tertarik melakukan pembelajaran fisika yang berbasis environmental learning dengan harapan akan membuat pelajaran fisika lebih mudah difahami dan membuat suasana baru dengan mengkaitkan materi fisika dengan lingkungan sehingga peserta didik juga dapat mengetahui manfaat yang diperoleh dalam mempelajari ilmu fisika di sekolah. Hal ini juga didukung dengan adanya beberapa hasil penelitian yang relevan dan digunakan untuk mendukung penelitian ini antara lain (1) Hasil penelitian (Khanafiyah \& Yulianti, 2013) dengan judul Model Problem Based Instruction pada Perkuliahan Fisika Lingkungan Untuk Mengembangkan Sikap Kepedulian Lingkungan yang memiliki hasil dimana dapat meningkatkan sikap peduli lingkungan dan kemampuan dalam memecahkan masalah lingkungan, (2) Hasil penelitian dari (Agil, 2015) berjudul Pengembangan Bahan Ajar Berbasis Inkuiri Terintegrasi Nilai Karakter peduli Lingkungan Pada Materi Ekosistem menunjukkan bahwa kualitas pembelajaran inkuiri yang terintegrasi nilai karakter peduli lingkungan memiliki nilai presentase yang cukup tinggi dan bahan ajar harus selalu direvisi secara betahap agar mendapatkan hasil yang lebih baik, (3) Penelitian dari (Hasbullah, Nurpadillah, \& jamilah, 2018) yang berjudul Pengaruh Metode Pembelajaran Inkuiri Berbasis Fenomena Terhadap Kemampuan Berfikir Kritis memiliki hasil bahwa terdapat pengaruh kemampuan berfikir kritis yang signifikan antara kelas kontrol dan kelas eksperimen, (4) Penelitian dari (Ilham \& Qaddafi, 2015) dengan judul Efektivitas PenggunaanModul Berbasis Lingkungan Terhadap Hasil Belajar Peserta Didik Kelas VII SMP Negeri 28 Bulukumba yang memiliki nilai presentase yang tinggi terhadap peningkatan hasil belajar peserta didik.

Berdasarkan respon peserta didik tersebut maka memiliki arti bahwa peserta didik memiliki ketertarikan apabila dalam pelaksanaan pembelajaran fisika dilakukan dengan berbasis environmental learning. Pembelajaran berbasis environmental learning ini dapat menjadi salah satu cara yang dapat digunakan dalam melakukan pembelajaran fisika yang asik dan tidak mudah membuat peserta didik menjadi bosan dan jenuh serta dapat menumbuh kembangkan kemampuan peserta didik dalam menganalisis suatu permasalah dalam kehidupan sehari-hari menggunakan ilmu fisika.

\section{KESIMPULAN}

Berdasarkan data yang telah diperoleh dalam penelitian ini, dapat disimpulkan bahwa 95\% dari peserta didik yang mengisi angket memberikan respon positif. Respon tersebut berisi bahwa peserta didik tertarik apabila pembelajaran fisika dilakukan dengan pendekatan berbasis environmental learning 
dengan harapan agar peserta didik merasa lebih mudah memahami materi fisika dan memberikan pengalaman belajar yang baru serta dapat menerapkan ilmu fisika dalam kegiatan di lingkungan sekitar.

Saran yang diberikan oleh peserta didik kepada guru adalah untuk melaksanakan proses pembelajaran yang inovatif sehingga peserta didik merasa memiliki ketertarikan dalam pelaksanaan proses pembelajaran. Penyampaian materi diharapkan dapat memberikan pengalaman baru dan dapat menerapkannya pada lingkungan sekitar sehingga proses pembelajaran tidak hanya dengan pemberian materi, rumus-rumus, dan latihan soal. Dilakukannya proses pembelajaran yang berbasis environmental learning diharapkan dapat menjadi salah satu metode yang tepat dengan memberikan hasil yang baik serta dapat menumbuh kembangkan kemampuan peserta didik dalam menalar dan melestarikan lingkungan sekitar.

\section{DAFTAR PUSTAKA}

Affandy, H., Aminah N. S., Supriyanto, A. 2019. Analisis Keterampilan Berfikir Kritis Siswa Pada Materi Fluida Dinamis di SMA Batik 2 Surakarta. Jurnal Materi dan Pembelajaran Fisika, 9(1), 25-33.

Agil, L. 2015. Pengembangan Bahan Ajar Berbasis Inkuiri Terintegrasi Nilai Karakter Peduli Lingkungan Pada Materi Ekosistem. BIOEDUKASI Jurnal Pendidikan Biologi, 6(2), 143-147.

Bunga, D. I., Sumarmi, Astina, K. 2019. Pembelajaran Lingkungan Berbasis Kearifan Lokal dengan Model Experiential Learning. Jurnal Pendidikan Teori Penelitian dan Pengembangan, 4(5), 648-653.

Hasbullah A., Nurpadilah, Jamilah. 2018. Pengaruh Metode Pembelajaran Inquiry Berbasis Fenomena Terhadap Kemampuan Berpikir Kritis. Jurnal Pendidikan Fisika, 6(2), 51-56.

Hedge, B. \& Meera, B.N. 2012. How Do They Solve It? An Insight into the learner's approach to the mechanism of physics problem solving. Physics Education Research, 8(1), 010109,1-9.

Hosnan, Muhammad. 2014. Pendekatan Saintifik dan Kontekstual dalam Pembelajaran Abad 21. Bogor : Ghalia Indonesia.
Ilham, A. B., Qaddafi, M. 2015. Efektivitas Penggunaan Modul Berbasis Lingkungan Terhadap Hasil Belajar Peserta Didik Kelas VII SMP Negeri 28 Bulukumba. Jurnal Pendidikan Fisika UIN Alauddin, 3(2), 110-114.

Imelda, A. Dewi. 2019. Respon Siswa Terhadap Pembelajaran Problem Based Learning Dalam Meningkatkan Higher Order Thingking Skills. Journal of Mathematics Education and Science, 5(1), $1-9$

Khanafiyah, S., D. Yulianti. 2013. Model Problem Based Instruction pada Perkuliahan Fisika Lingkungan Untuk Mengembangkan Sikap Kepedulian Lingkungan. Jurnal Pendidikan Fisika Indonesia, 9(2013), 35-42.

Maman, S., Muris., Jasruddin. 2016. Pengembangan Media Pembelajaran Fisika Berbasis Lingkungan Dengan Memanfaatkan Komputer Siswa Kelas X SMA Negeri 1 Ulaweng. Jurnal Sains dan Pendidikan Fisika, 12(2), 136-145

Mastuti, E. 2016. Pemanfaatan Teknologi Dalam Menyusun Evaluasi Hasil Belajar : Kelebihan dan Kelemahan "Tes Online" Untuk Mengukur Hasil Belajar Mahasiswa. Jurnal Penelitian Psikologi, 7(1), 10-19

Mulyadi, M. 2011. Penelitian Kuantitatif dan Kualitatif Serta Pemikiran Dasar Menggabungkannya. Jurnal Studi Komunikasi dan Media, 15(1), 127-138.

Nobita, N. 2015. Perbedaan Prestasi Belajar Fisika Antara Peserta Didik Yang Diajar Dengan Metode Levels of Inquiry Learning Cycle dan Metode Ceramah. Jurnal Manajemen Pendidikan, 2(1), 110125.

Periera, S. (2017). Culture Recognition Through Sociology Learning for Timor Leste Students. ISLLAC: Journal of Intensive Studies on Language, Literature, Art, and Culture, 1(1), 119-139.

Rahayu, S. 2012. Designed Student-Centered Instruction (DSCI) : Model Pembelajaran Berbasis Konstruktivistik, Inkuiri dan Kontekstual. Makalah disampaikan pada Seminar Nasional Kimia dan Pendidikan Kimia FKIP UNS, 31 Maret 2012.

Rickinson, M., Lundholm, C., dan Hopwood, N. (2019). Environmental Learning. Insights from Research into the Student Experience. Dortrecht : Springer. 
Rohani, O. E. Marjani., Sulha. 2018. Peningkatan Hasil Belajar Siswa Dalam Pembelajaran Pendidikan Kewarganegaraan Melalui Penerapan Model Pembelajaran Snowball Throwing. Jurnal Pendidikan Kewarganegaraan, 2(2), 10-19.

Samudra, G. B., Suastra, I Wayan., Suma, Ketut. 2014. Permasalahan-Permasalahan yang Dihadapi Siswa SMA di Kota Singaraja dalam Mempelajari Fisika. Jurnal Program Pascasarjana Universitas Pendidikan Ganesha, 4(1), 1-7.

Setyosari, Punaji. 2012. Metode Penelitian Pendidikan dan Pengembangan. Jakarta : Kencana.

Simanjuntak, S.D., Imelda. 2018. Respon Siswa Terhadap Pembelajaran Realistik Dengan Konteks Budaya Batak Toba. MES : Journal Of Mathematics Education and Science, 4(1), 81-88.

Subagia, I Wayan. 2013. Implementasi Pendekatan Ilmiah Dalam Kurikulum 2013 Untuk Mewujudkan Tujuan Pendidikan Nasional. Artikel Seminar Nasional FMIPA UNDIKSHA III.
Sudjana, N. 2010. Dasar-dasar Proses Mengajar. Bandung: Sinar Baru Algesindo.

Suparni. 2015. Meningkatkan hasil belajar IPA pada materi mengenal sifat benda dan kegunaannya dengan media realita pada siswa kelas 1 B SDN Sidomekar 08 Jember. Jurnal Pancaran, 4(3), 11- 20.

Trianto. 2007. Model-model Pembelajaran Inovatif Berorientasi Konstruktivistik. Jakarta : Bumi Aksara.

Vaselinovska, S.S., Gudeva, L.K., \& Djokic, M. 2011. The effect of teaching methods on cognitive achievement in biology studying. Procedia Social and Behavioral Science, . 15(1), 2521-2527.

Venkataramanan, M and Smitha. 2011. Causes And Effects Of Global Warming. Indian Journal of Science Technology, 4(3), 226229. 